\title{
Vulnerability of Dentate Granule Cells to Disruption of Arc Expression in Human Amyloid Precursor Protein Transgenic Mice
}

\author{
Jorge J. Palop, ${ }^{1,2}$ Jeannie Chin, ${ }^{1,2}$ Nga Bien-Ly, ${ }^{1}$ Catherine Massaro, ${ }^{1,3}$ Bertrand Z. Yeung, ${ }^{1}$ Gui-Qiu Yu, ${ }^{1}$ and \\ Lennart Mucke ${ }^{1,2,3}$ \\ ${ }^{1}$ Gladstone Institute of Neurological Disease, ${ }^{2}$ Department of Neurology, and ${ }^{3}$ Neuroscience Graduate Program, University of California, San Francisco, \\ San Francisco, California 94158
}

\begin{abstract}
Activity-induced expression of Arc is necessary for maintenance of long-term potentiation and for memory consolidation. In transgenic (TG) mice with neuronal production of human amyloid precursor protein (hAPP) and hAPP-derived amyloid- $\beta$ (A $\beta$ ) peptides, basal Arc expression was reduced primarily in granule cells of the dentate gyrus. After exploration of a novel environment, Arc expression in these neurons was unaltered in hAPP mice but increased markedly in nontransgenic controls. Other TG neuronal populations showed no or only minor deficits in Arc expression, indicating a special vulnerability of dentate granule cells. The phosphorylation states of NR2B and ERK1/2 were reduced in the dentate gyrus of hAPP mice, suggesting attenuated activity in NMDA-dependent signaling pathways that regulate synaptic plasticity as well as Arc expression. Arc reductions in hAPP mice correlated with reductions in the actin-binding protein $\alpha$-actinin-2, which is located in dendritic spines and, like Arc, fulfills important functions in excitatory synaptic activity. Reductions in Arc and $\alpha$-actinin-2 correlated tightly with reductions in Fos and calbindin, shown previously to reflect learning deficits in hAPP mice. None of these alterations correlated with the extent of plaque formation, suggesting a plaque-independent mechanism of hAPP/A $\beta$ induced neuronal deficits. The brain region-specific depletion of factors that participate in activity-dependent modification of synapses may critically contribute to cognitive deficits in hAPP mice and possibly in humans with Alzheimer's disease.
\end{abstract}

Key words: Alzheimer; dendritic spines; immediate-early gene; NMDA; novel environment; plasticity

\section{Introduction}

Alzheimer's disease $(\mathrm{AD})$ results in progressive impairment of memory consolidation. Memory retrieval is also affected in a characteristic pattern, in which recent memories are more vulnerable than older memories (Eustache et al., 2004; Sadek et al., 2004). These impairments suggest an early vulnerability of the hippocampus and a subsequent disruption of neocortical networks sustaining consolidated memories (Wiltgen et al., 2004). Although the differential loss of neurons in specific brain regions in AD has been mapped carefully (Braak and Braak, 1991; West et al., 1991; Corder et al., 2000), little is known about the neuronal populations that first become dysfunctional, and even less about the underlying molecular mechanisms. Understanding the processes that cause neuronal dysfunction in $\mathrm{AD}$ and related models could guide the development of treatments to prevent $\mathrm{AD}$, pre-

Received March 14, 2005; revised Aug. 15, 2005; accepted Aug. 17, 2005.

This work was supported in part by National Institutes of Health Grants AG023501, AG11385, AG022074, and NS41787 to L.M. We thank S. Chowdhury and P. F. Worley for the full-length mouse Arc CDNA clone and the Arc antibody; P. Seubert and L. McConlogue for the 3D6 antibody; I. Cobos for advice on in situ hybridization; X. Wang and H. Ordanza for technical support; $S$. Finkbeiner, S. Mitra, and V. Rao for helpful comments on this manuscript; $G$. Howard and S. Ordway for editorial review; and D. McPherson and L. Manuntag for administrative assistance.

Correspondence should be addressed to Dr. Lennart Mucke, Gladstone Institute of Neurological Disease, 1650 Owens Street, San Francisco, CA 94158. E-mail: Imucke@gladstone.ucsf.edu.

D01:10.1523/JNEUROSCI.2829-05.2005

Copyright $\odot 2005$ Society for Neuroscience $\quad$ 0270-6474/05/259686-08\$15.00/0 serve learning and memory in its early stages, and maximize cognitive functions in the later stages of the illness.

Transgenic (TG) mouse models with neuronal production of human amyloid precursor protein (hAPP) and hAPP-derived amyloid- $\beta(\mathrm{A} \beta)$ peptides develop a range of $\mathrm{AD}$-like alterations, including age-dependent deficits in learning and memory (Higgins and Jacobsen, 2003; Walsh and Selkoe, 2004; Kobayashi and Chen, 2005). However, the cellular and molecular substrates of these cognitive deficits remain to be identified. Our previous analysis of hAPP mice (Palop et al., 2003) and reports by others (Dickey et al., 2003, 2004) suggested that the depletion of synaptic activity-dependent proteins may play a critical role in $\mathrm{A} \beta$ induced cognitive decline. Particularly intriguing to us in this context were alterations in the immediate-early gene product Arc (activity-regulated cytoskeleton-associated protein), the expression of which has been used previously to image cellular networks involved in encoding of contextual information (Guzowski et al., 1999; Burke et al., 2005).

Arc is expressed predominantly in cortical and hippocampal glutamatergic neurons; it is required for maintenance of longterm potentiation (LTP) and for memory consolidation (Lyford et al., 1995; Guzowski et al., 2000; Steward and Worley, 2001). Stimulated neurons rapidly increase Arc mRNA expression, which allows for the identification of neuronal network activity (Lyford et al., 1995; Guzowski et al., 1999; Temple et al., 2003; 
Vazdarjanova and Guzowski, 2004). Furthermore, Arc mRNA is induced in activated neuronal ensembles in the hippocampus that respond to specific environments, providing a potential network mechanism for encoding spatial and contextual information (Guzowski et al., 1999; Vazdarjanova and Guzowski, 2004).

To further elucidate the role of Arc and related factors in $\mathrm{hAPP} / \mathrm{A} \beta$-induced neuronal deficits in vivo, we studied hAPP TG mice that have high levels of $A \beta$ in the hippocampus and neocortex and that develop age-related synaptic deficits as well as impairments in learning and memory (Hsia et al., 1999; Mucke et al., 2000; Palop et al., 2003). We monitored Arc expression in their brains at baseline and after behavioral or pharmacological stimulation to determine whether $\mathrm{A} \beta$ affects $A r c$ expression differentially in different neuronal populations, whether it affects only induced or also basal Arc expression, whether the reported block to Arc induction can be overcome by pharmacological stimulation of excitatory neurotransmitter receptors, and whether disruption of Arc expression depends on the parenchymal deposition of fibrillar $\mathrm{A} \beta$ in amyloid plaques. We also tested whether Arc expression deficits may be linked to deficits in other synaptic plasticity-related factors, including alterations in the NMDA-mediated signaling pathway.

\section{Materials and Methods}

TG mice. We studied 5- to 8-month-old heterozygous TG and nontransgenic (NTG) mice from lines J20 and I5. Line J20 expresses hAPP carrying the Swedish and Indiana FAD (familial AD) mutations (hAPP $\mathrm{FAD}_{\mathrm{FD}}$ ), and line I5 expresses wild-type hAPP (hAPP $\mathrm{wT}_{\mathrm{WT}}$ ) at comparable levels (Mucke et al., 2000). In both lines, neuronal expression of hAPP is directed by the platelet-derived growth factor (PDGF) $\beta$-chain promoter. Mice were $\mathrm{N}_{12}-\mathrm{N}_{15}$ offspring from crosses between heterozygous TG mice and C57BL/6J NTG breeders. Gender had no detectable effect on any of the parameters analyzed (data not shown). All experiments were approved by the Committee on Animal Research of the University of California, San Francisco.

Novel environment. Four to $5 \mathrm{~d}$ before the experiment, female mice

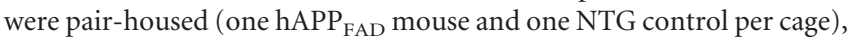
whereas male mice were singly housed. Mice assigned to novel environment exploration were then transferred to a larger cage $(45 \times 25 \times 20$ $\mathrm{cm}$ ) in an adjacent room. The new room differed markedly in size, shape, light, and furnishing. The new cage was uncovered and contained different bedding and five novel objects. The mice were allowed to explore the new environment for $2 \mathrm{~h}$; the remaining mice stayed undisturbed in their home cages.

The activity (ambulatory movements, rearing, sniffing, digging) of the mice and their interactions with the novel objects were quantified from video records during the first $10 \mathrm{~min}$ of each hour in the new cage. An object-interaction event was defined as any close exploratory activity with any novel object. Observers were blinded to genotype. After the observation period, alternate groups of mice assigned to the home cage or novel environment conditions were taken to an adjacent room, deeply anesthetized, and perfused transcardially.

Kainate injections. Kainate (Sigma, St. Louis, MO) was dissolved in PBS to $1.8 \mathrm{mg} / \mathrm{ml}$ for intraperitoneal injection. All mice (three TG and three NTG) given injections of $18 \mathrm{mg} / \mathrm{kg}$ kainate displayed tonic-clonic seizures starting 10-45 min after the injection. Of 28 mice (16 TG and 12 NTG) given injections of $10 \mathrm{mg} / \mathrm{kg}$ kainate, only one TG mouse developed seizure activity and was excluded from additional analyses. All mice were killed $2 \mathrm{~h}$ after the injection.

Tissue preparation. Anesthetized mice were flush-perfused transcardially with phosphate buffer, followed by $4 \%$ phosphate-buffered paraformaldehyde. The brains were removed and drop-fixed with the same fixative at $4^{\circ} \mathrm{C}$ for $48 \mathrm{~h}$. After rinsing with $\mathrm{PBS}$, brains were transferred to $30 \%$ sucrose in $\mathrm{PBS}$ at $4^{\circ} \mathrm{C}$ for $24 \mathrm{~h}$ and coronally sectioned with a sliding microtome. Ten subseries of floating sections $(30 \mu \mathrm{m})$ were collected per mouse and kept at $-20^{\circ} \mathrm{C}$ in cryoprotectant medium until use. Each subseries contained sections throughout the rostrocaudal extent of the forebrain. All solutions were prepared with autoclaved water containing $0.1 \%$ diethyl pyrocarbonate and filtered (pore size, $0.22 \mu \mathrm{m}$ ).

In situ hybridization. Antisense and sense cRNA probes were generated from a linearized plasmid containing full-length $\operatorname{Arc} \mathrm{cDNA}(\sim 3 \mathrm{kbp})$ with T7 and T3 polymerase (Promega, Madison, WI) and premixed RNA-labeling nucleotide mixes containing digoxigenin (Roche Molecular Biochemicals, Palo Alto, CA). The yield and integrity of cRNA riboprobes was confirmed by gel electrophoresis. In situ hybridization was performed on floating coronal sections $(30 \mu \mathrm{m})$. After removing cryoprotectant medium with PBS, floating sections were fixed in $4 \%$ buffered paraformaldehyde, treated with $0.005 \%$ proteinase $\mathrm{K}$ in Tris- $\mathrm{HCl}$, $\mathrm{pH}$ 8.0, EDTA, and $0.5 \%$ Tween for $15 \mathrm{~min}$, and incubated with $1.335 \%$ triethanolamine, $0.175 \% \mathrm{HCl}$, and $0.25 \%$ acetic anhydride for $10 \mathrm{~min}$. Between steps, sections were washed three times with PBS and $0.5 \%$ Tween at room temperature. Sections were then incubated with prehybridization buffer containing $50 \%$ formamide, $5 \times$ SSC, $5 \times$ Denhardt's solution, salmon sperm DNA, and yeast tRNA for $4-6 \mathrm{~h}$ at room temperature. Riboprobes were diluted in the prehybridization buffer, heated to $70^{\circ} \mathrm{C}$, and added to the sections. Hybridization was done at $67^{\circ} \mathrm{C}$ for $16 \mathrm{~h}$. Hybridized sections were washed once with $5 \times$ SSC, followed by washes in $0.2 \times \mathrm{SSC}$ at $67^{\circ} \mathrm{C}$ for $4 \mathrm{~h}$. Sections were transferred to Tris, saline, and $0.5 \%$ Tween buffer, blocked with $10 \%$ heat-inactivated sheep serum, and incubated overnight with sheep anti-digoxigenin-alkaline phosphatase (1:5000; Roche Molecular Biochemicals). Finally, nitroblue tetrazolium/5-bromo-4-chloro-3-indolyl phosphate (1:50; Roche Molecular Biochemicals) in NTMT (100 mM NaCl, $100 \mathrm{~mm}$ Tris-HCl, pH 9.5, $50 \mathrm{mM} \mathrm{MgCl}_{2}, 0.1 \%$ Triton X-100) buffer was used to visualize the signal. No signal was detected when sense Arc riboprobe was used (data not shown).

Immunohistochemistry. Microtome sections $(30 \mu \mathrm{m})$ were stained with the standard avidin-biotin/peroxidase method. Briefly, after quenching endogenous peroxidase activity and blocking nonspecific binding, sections were incubated with rabbit anti-Arc (1:8000; a gift from S. Chowdhury and P. F. Worley, Johns Hopkins University School of Medicine, Baltimore, MD), rabbit anti-calbindin (1:15,000; Swant, Bellinzona, Switzerland), mouse anti- $\alpha$-actinin-2 (1:10,000; Sigma), or biotinylated mouse anti-A $\beta$ (1:500, 3D6; Elan Pharmaceuticals, South San Francisco, CA) antibody. Nonbiotinylated primary antibodies were detected with biotinylated goat anti-rabbit (1:200; Vector Laboratories, Burlingame, CA) or donkey anti-mouse (1:500; Jackson ImmunoResearch, West Grove, PA) antibody. Diaminobenzidine was the chromagen.

Quantitative analysis of brain sections. Arc mRNA and Arc immunoreactivity (IR) were quantitated as described previously (Temple et al., 2003). Heavily labeled Arc-expressing cells in the granular layer were counted in every 10th section throughout the rostrocaudal extent of this layer with a $20 \times$ objective by an investigator blinded to genotype and treatment. Results are presented as the total number of positive cells counted per hemibrain. For each mouse, closely matching results were obtained in the opposite hemibrain (data not shown). Quantitations were confirmed by two independent experimenters (data not shown).

The relative levels of Arc mRNA and Arc IR in the CA1 pyramidal layer, CAl stratum radiatum, and neocortex (primary somatosensory cortex) were quantitated by measuring the integrated optical density (IOD) in three sections ( $30 \mu \mathrm{m}$ thick, $300 \mu \mathrm{m}$ apart) between -1.70 and $-2.80 \mathrm{~mm}$ from bregma with the BioQuant Image Analysis System (R\&M Biometrics, Nashville, TN). Two IOD measurements per region and section were taken. The intensity of Arc mRNA labels in NTG mice removed directly from their home cage was defined as 1 . Relative levels of Arc IR were obtained by determining in each section the ratio between IOD values in the region of interest and IOD values in the thalamus (background IR). Arc expression in the respective regions of other mice was expressed relative to this baseline. IRs for calbindin, $\alpha$-actinin-2, Fos, and A $\beta$ (plaque load) were quantified as described previously (Palop et al., 2003).

Western blot analysis. A McIlwain tissue chopper was used to cut hemibrains into $450-\mu \mathrm{m}$-thick horizontal sections from which the dentate gyrus was microdissected on ice. For protein quantifications, dentate gyrus samples from each hemibrain were pooled and homogenized on ice in buffer containing $320 \mathrm{~mm}$ sucrose, $10 \mathrm{~mm}$ Tris- $\mathrm{HCl}, \mathrm{pH}$ 7.4, $10 \mathrm{~mm}$ EDTA, $10 \mathrm{~mm}$ EGTA, 1\% deoxycholate, protease inhibitor mixture 
(Roche Molecular Biochemicals), and phosphatase inhibitor mixtures I and II (Sigma). Samples were then briefly sonicated on ice and centrifuged at $5000 \times g$ for $10 \mathrm{~min}$. Equal amounts of protein (determined by the Bradford assay) were resolved by SDS-PAGE on $4-12 \%$ gradient gels and transferred to nitrocellulose membranes. For analysis of phosphoproteins, membranes were labeled with antipY1472 antibody (1:1000 rabbit polyclonal; Chemicon, Temecula, CA) or anti-dually phosphorylated extracellular signal-regulated kinase 1/2 (ERK1/2; 1:2500 rabbit polyclonal; Cell Signaling, Beverly, MA), followed by incubation with HRP-conjugated goat anti-rabbit IgG (1:5000; Chemicon) secondary antibody. For analysis of total protein levels, blots were stripped and reprobed with anti-NR2B antibody (1:10,000 rabbit polyclonal; Chemicon) or anti-pan-ERK1/2 (1:2,500 rabbit polyclonal; Cell Signaling). Bands were visualized by ECL and quantitated densitometrically with Quantity One 4.0 software (Bio-Rad, Hercules, CA).

Statistical analysis. Statistical analyses were performed with SPSS 10.0 (SPSS, Chicago, IL). Differences between means were assessed by unpaired, two-tailed Student's $t$ test or by ANOVA, followed by Tukey-Kramer post hoc test. Differences between expected and observed frequencies were assessed by $\chi^{2}$ test. Correlations were examined by simple regression analysis. Null hypotheses were rejected at the 0.05 level.

\section{Results}

Brain region-specific decreases in basal and induced Arc expression in hAPP $_{\text {FAD }}$ mice

In NTG controls removed directly from their home cage, basal Arc mRNA expression in the forebrain was widespread and relatively uniform in cortical and hippocampal pyramidal neurons but more discrete in the dentate gyrus, where scattered granule cells exhibited high levels of labeling (Fig. 1A,C). This expression pattern is consistent with previous reports (Lyford et al., 1995; Temple et al., 2003). Basal Arc expression in hAPP $\mathrm{FAD}_{\text {mice was }}$ similar, except for a prominent reduction in $A r c$-expressing granule cells (Figs. $1 A, 2 C-F$ ). It should be noted in this context that the PDGF promoter used in these mice directs widespread neuronal production of hAPP/A $\beta$ in different lines of TG mice (Games et al., 1995; Rockenstein et al., 1995; Mucke et al., 2000).

To determine whether granule cells of $\mathrm{hAPP}_{\mathrm{FAD}}$ mice upregulate $A r c$ expression when a new context is encountered, mice were allowed to explore a novel environment for $2 \mathrm{~h}$. In NTG mice, environmental exploration markedly increased Arc expression in all regions expressing $A r c$ at baseline (Figs. $1 B, C, 2 A, C-F$ ), consistent with previous findings (Temple et al., 2003). In hAPP $\mathrm{FAD}_{\mathrm{F}}$ mice, exploration significantly increased Arc expression in the CA1 pyramidal layer, CA1 stratum radiatum, and neocortex, but not in granule cells, which showed no evidence of Arc induction (Figs. $1 B, 2 B, C-F$ ).

To investigate whether the Arc expression deficit in $\mathrm{hAPP}_{\mathrm{FAD}}$

\section{Home cage B Novel environment}
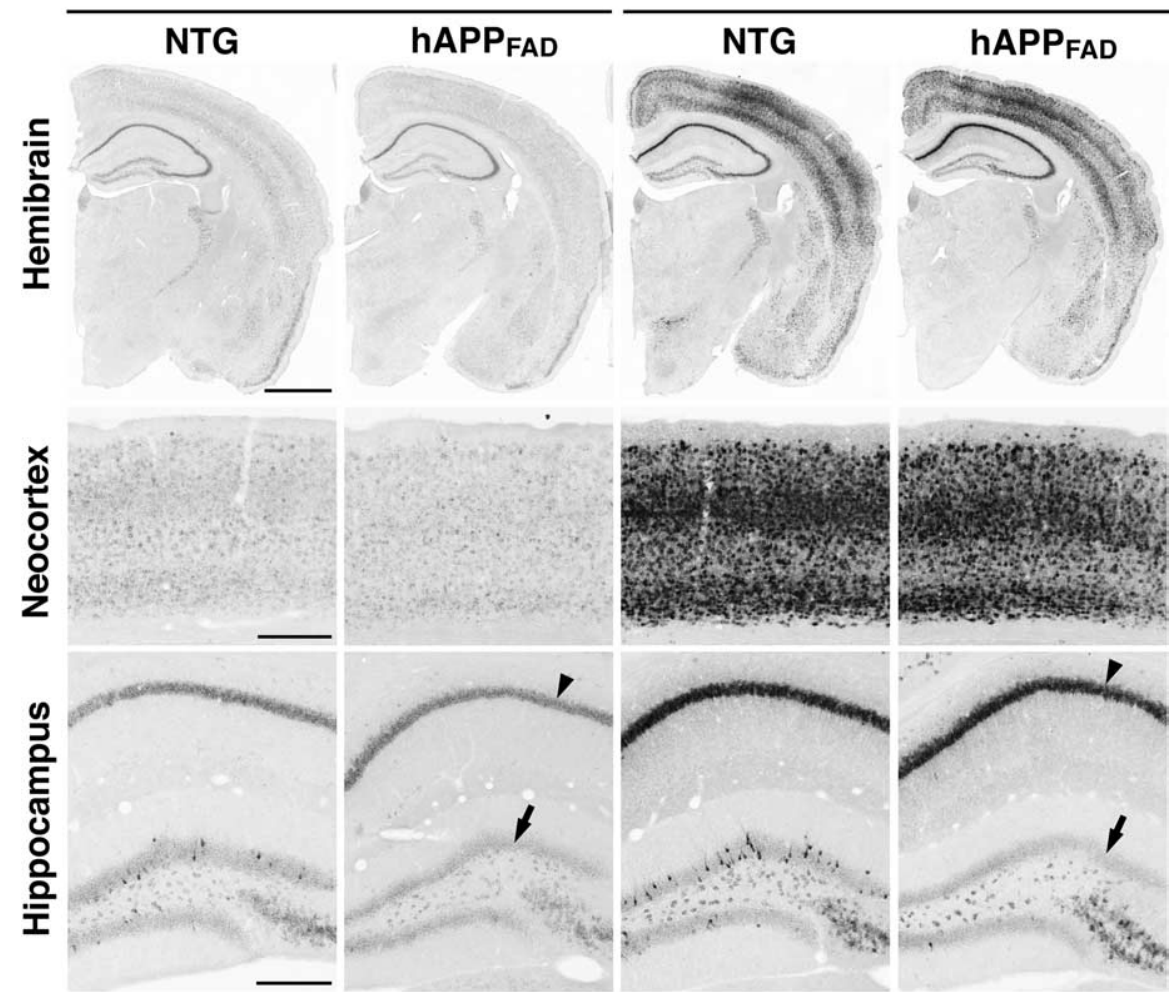

CA1 pyramidal layer

Granular layer

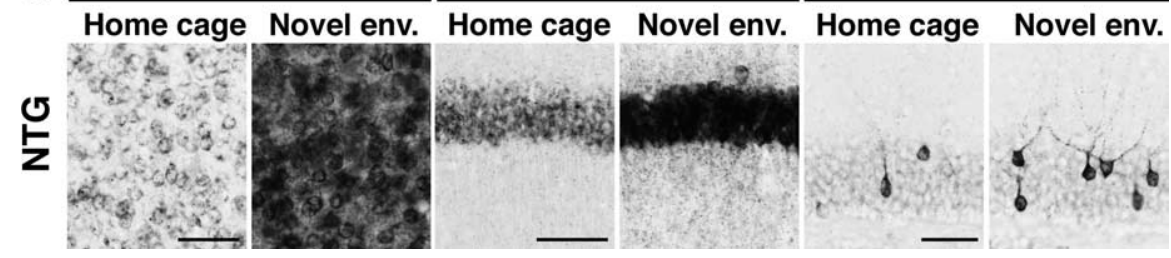

Figure 1. Brain region-specific deficits in basal and stimulated Arc expression in $h A P P_{F A D}$ mice. NTG and TG (hAPP $\left.F A D\right)$ mice were placed into a novel environment or left in their home cage. Two hours later, they were anesthetized and perfused transcarand hippocampus of mice maintained in the home cage. $\boldsymbol{B}$, Arc mRNA levels in mice that had explored the new environment. Note and ment. Scale bars: $\boldsymbol{A}, \boldsymbol{B}, 1 \mathrm{~mm}$ (top), $250 \mu \mathrm{m}$ (middle, bottom); $\boldsymbol{C}, 50 \mu \mathrm{m}$.

mice was also evident at the protein level, we labeled brain sections with an anti-Arc antibody. Environmental exploration markedly increased Arc IR in cortical and hippocampal areas in NTG mice (Fig. 3). Arc IR was concentrated in neuronal nuclei in mice that explored the novel environment but not in mice that were maintained in the home cage (data not shown). In hAPP $\mathrm{FAD}$ mice that explored the novel environment, Arc IR levels increased in the pyramidal layer and stratum radiatum of CA1, as well as in the neocortex, but not in the granular layer of the dentate gyrus (Fig. 3B-F). Inductions of Arc IR in the CA1 region and the neocortex were similar in magnitude in $\mathrm{hAPP}_{\mathrm{FAD}}$ mice and NTG controls (Fig. 3D-F).

To determine whether the granule cell induction of other immediate-early genes was also affected in hAPP $\mathrm{FAD}_{\text {mice, we }}$ examined the expression of Fos. At baseline, hAPP $\mathrm{FAD}_{\text {mice had }}$ fewer Fos-immunoreactive granule cells than NTG controls (Fig. $4 A, C$ ), consistent with previous observations (Palop et al., 2003). 

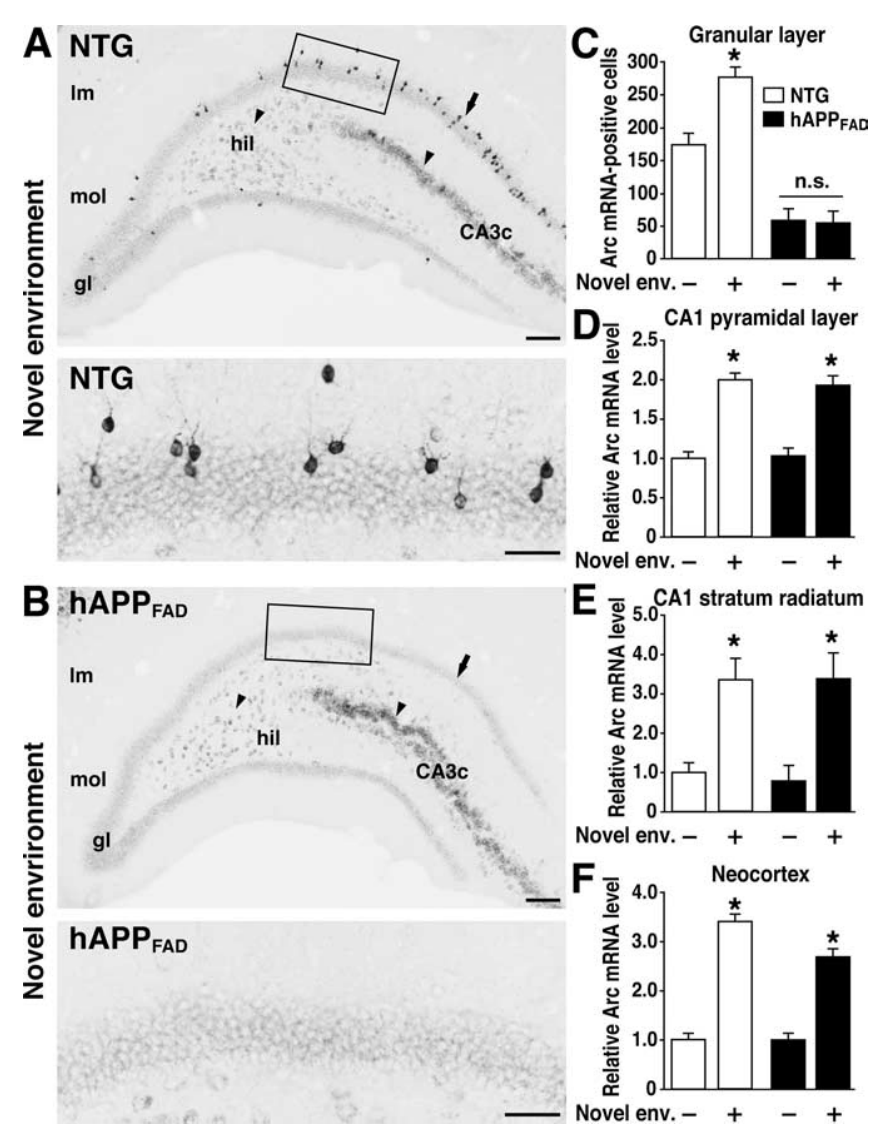

Figure 2. Lack of Arc induction in granule cells of $\mathrm{hAPP}_{\mathrm{FAD}}$ mice after exploration of a novel environment. $A, B$, In situ hybridization illustrates the heterogeneity of Arc-expressing cells in the dentate gyrus and the differential susceptibility of distinct neuronal populations to impair-

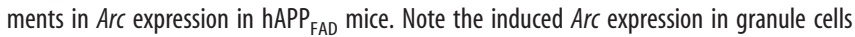
(arrow), hilar cells (arrowhead), and proximal CA3c pyramidal cells (arrowhead) in an NTG mouse $(A)$ and the selective absence of Arc mRNA induction in the granule cells (arrow) of an $\mathrm{hAPP}_{\mathrm{FAD}}$ mouse $(\boldsymbol{B})$. The bottom panels depict higher-magnification images from the squared regions in $\boldsymbol{A}$ and $\boldsymbol{B}$. Scale bars: top, $100 \mu \mathrm{m}$; bottom, $50 \mu \mathrm{m}$. Im, Stratum lacunosum-moleculare; mol, molecular layer; $g l$, granular layer; hil, hilus. C-F, Quantitation of Arc expression at baseline and after exploration of a novel environment (Novel env.). The number of Arc-positive granule cells and the optical density of in situ hybridization labels in other brain regions were assessed in coronal sections from NTG controls $(\square)$ and hAPP FAD mice $(\square)$ that had $(+)$ or had not ( - ) explored a novel environment ( $n=11-12$ per genotype and condition). hAPP FAD mice had significantly fewer Arc-positive cells in the granular layer of the dentate gyrus than NTG controls, both at baseline and after exploration (C). Basal levels of Arc mRNA in the CA1 pyramidal layer $(\boldsymbol{D}), \mathrm{CA} 1$ stratum radiatum $(\boldsymbol{E})$, and neocortex $(\boldsymbol{F})$ were similar in $\mathrm{hAPP}_{\mathrm{FAD}}$ mice and NTG controls. In both groups, Arc mRNA expression in these regions increased robustly after exploration of the novel environment. ${ }^{*} p<0.01$ versus home-caged group of the same genotype (Tukey-Kramer test). Error bars indicate SEM. n.S., Nonsignificant.

After environmental exploration, hAPP $\mathrm{FAD}_{\mathrm{F}}$ mice showed no increase in the number of Fos-immunoreactive granule cells, whereas NTG mice showed a robust increase (Fig. $4 B, C$ ). In contrast, Fos induction in the CA1 pyramidal layer was similar in $\mathrm{hAPP}_{\mathrm{FAD}}$ mice and NTG controls (Fig. 4A,B). Granule cell levels of Fos and Arc expression in hAPP $\mathrm{FAD}_{\mathrm{F}}$ mice were tightly correlated both at baseline $\left(R^{2}=0.82 ; p<0.001\right)$ and after environmental exploration $\left(R^{2}=0.84 ; p<0.001\right)$, suggesting that $\mathrm{hAPP} / \mathrm{A} \beta$ affects a regulatory mechanism common to different immediate-early genes.

To exclude the possibility that the deficits in Arc and Fos induction in $\mathrm{hAPP}_{\mathrm{FAD}}$ mice resulted from deficits in exploratory drive and a consequent lack of sensory stimulation, we monitored the motor activity of mice in the novel environment.
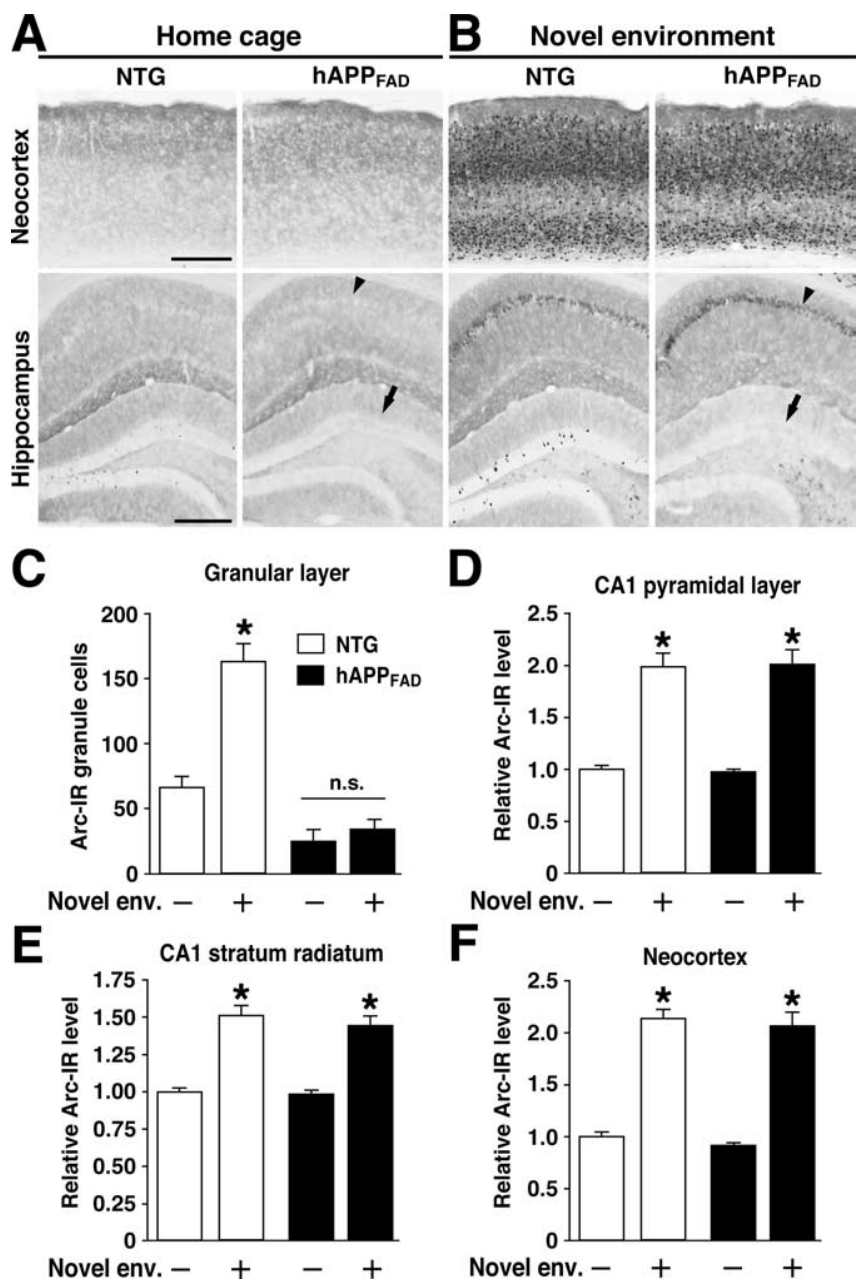

D

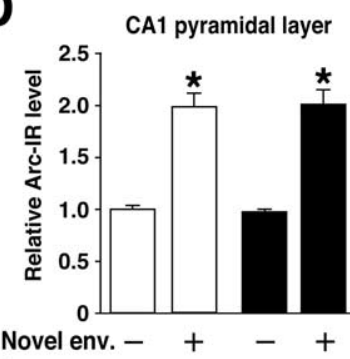

$\mathbf{F}$

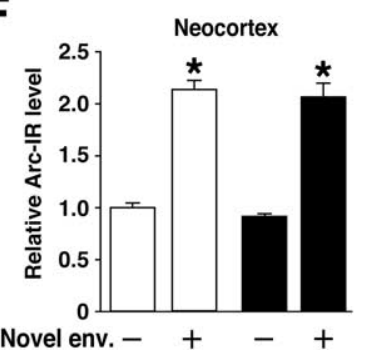

Figure 3. Brain region-specific Arc expression deficits in $\mathrm{hAPP}_{\mathrm{FAD}}$ mice are also detectable at the protein level. Arc immunostaining was performed on floating coronal sections. A, Basal levels of Arc IR in the neocortex and hippocampus of mice maintained in their home cage. $\boldsymbol{B}$, Arc-immunoreactive levels in mice that had explored a new environment. Note the increased Arc expression after environmental exploration in the neocortex and in the CA1 pyramidal layer (arrowheads) and the selective decrease in basal $(\boldsymbol{A})$ and stimulated $(\boldsymbol{B}) \operatorname{Arc}$ IR in the granular layer of hAPP ${ }_{\mathrm{FAD}}$ mice (arrows). Scale bars, $250 \mu \mathrm{m}$. C $\boldsymbol{F}$, Quantitation of Arc-immunoreactive levels. The number of Arc-immunoreactive granule cells and the optical density of immunolabels in other brain regions were assessed in NTG $(\square)$ and hAPP FAD $_{(}(\square)$ mice that had $(+)$ or had not $(-$ ) explored a novel environment (Novel env.; $n=11-14$ per genotype and condition). hAPP $_{\text {FAD }}$ mice had significantly fewer Arc-immunoreactive cells in the granular layer than NTG controls under basal conditions and showed no increase in Arc IR after exploration (C). Arc IR in the CA1 pyramidal layer $(\boldsymbol{D})$, CA1 stratum radiatum $(\boldsymbol{E})$, and neocortex $(\boldsymbol{F})$ were similar in

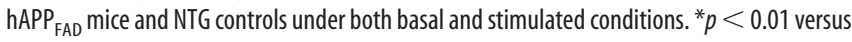
home-caged group of the same genotype (Tukey-Kramer test). Error bars indicate SEM. n.S., Nonsignificant.

hAPP ${ }_{\mathrm{FAD}}$ mice interacted more with the novel objects than NTG controls (Fig. 4D) and were slightly more active in general (data not shown), indicating that they had no deficits in exploratory drive.

\section{Resistance of hAPP ${ }_{\mathrm{FAD}}$ TG granule cells to Arc induction can} be overcome by kainate-induced seizure activity

To determine whether the deficits in Arc induction in granule cells of $\mathrm{hAPP}_{\mathrm{FAD}}$ mice are attributable to a general inability to upmodulate Arc expression, we challenged mice with a seizureinducing dose of kainate $(18 \mathrm{mg} / \mathrm{kg})$. After $2 \mathrm{~h}$, Arc expression increased markedly in granule cells of both NTG and hAPP $\mathrm{FAD}$ mice (Fig. 5A), indicating that granule cells of both groups can, in 

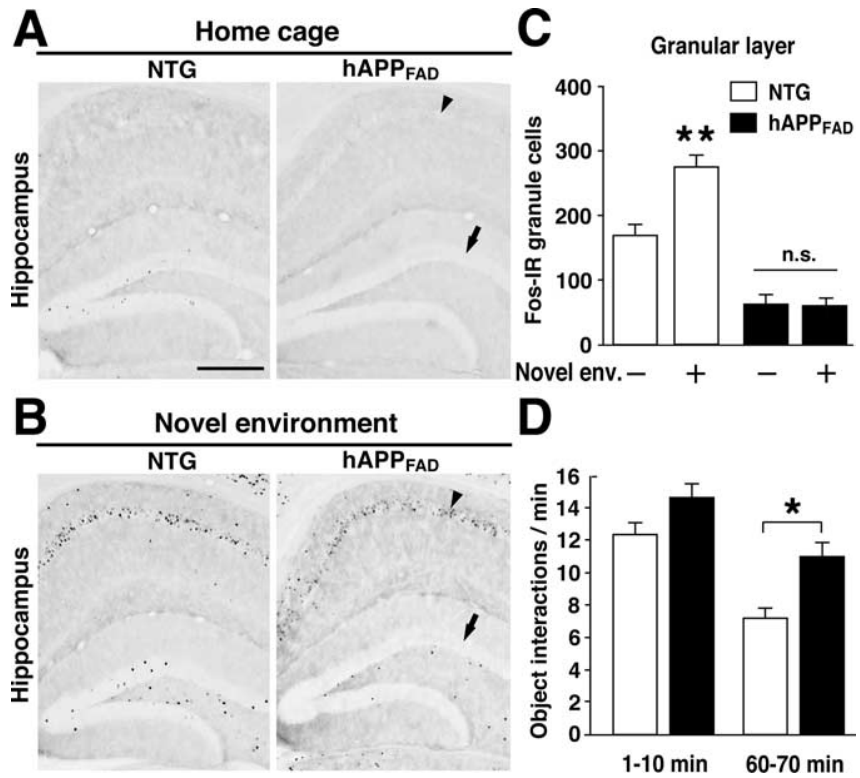

Figure 4. Granule cells of hAPP ${ }_{F A D}$ mice also fail to increase Fos expression after environmental exploration. $\boldsymbol{A}, \boldsymbol{B}$, Typical patterns of Fos IR in the hippocampus of mice that were kept in their home cage $(\boldsymbol{A})$ or allowed to explore a novel environment $(\boldsymbol{B})$. Note the lack of Fos induction in the granule cells (arrow) and the normal Fos induction in CA1 pyramidal cells (arrowhead) in hAPP FAD mice. Scale bar: $A, 250 \mu \mathrm{m}$. C, The number of Fos-positive granule cells was quantified in NTG $(\square)$ and hAPP FAD $_{(}(\square)$ mice that had $(+)$ or had not $(-)$ explored a novel

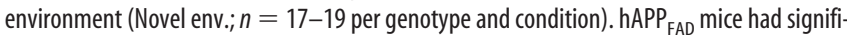
cantly fewer Fos-immunoreactive cells in the granular layer of the dentate gyrus than NTG controls, both at baseline and after exploration. ${ }^{* *} p<0.01$ versus home-caged group of the same genotype (Tukey-Kramer test). n.s., Nonsignificant. D, Object interactions in the novel environment were quantified from video records during two 10 min periods. ${ }^{*} p<0.05$ versus NTG (Student's $t$ test). Error bars indicate SEM. n.s., Nonsignificant.

fact, upmodulate Arc expression in response to this type of coordinated network stimulation.

To test whether hAPP $\mathrm{FAD}_{\mathrm{F}}$ mice have an increased threshold for kainate-mediated Arc induction, we challenged NTG and $\mathrm{hAPP}_{\mathrm{FAD}}$ mice with a lower dose of kainate $(10 \mathrm{mg} / \mathrm{kg})$, which did not elicit obvious seizure activity. Even this putatively nonepileptic dose of kainate elicited marked increases in granule cell Arc expression in some of the mice. Notably, a significantly lower proportion of hAPP $\mathrm{FAD}_{\mathrm{F}}$ mice than NTG mice had such marked Arc induction after receiving the lower dose of kainate (Fig. $5 B$ ). In the remainder of the mice, which showed less than maximal induction of Arc, the lower dose of kainate augmented Arc expression in granule cells only in NTG controls but not in hAPP ${ }_{\text {FAD }}$ mice (Fig. 5C,D).

\section{Deficits in Arc expression are independent of plaque}

deposition but influenced by $\mathrm{A} \beta$ levels

The synaptic and behavioral deficits we identified previously in different $\mathrm{hAPP}_{\mathrm{FAD}}$ lines were independent of the deposition of $\mathrm{A} \beta$ as amyloid plaques (Hsia et al., 1999; Mucke et al., 2000; Palop et al., 2003). In contrast, attenuated Arc induction identified by quantitative RT-PCR in the entire hippocampi of another line of $\mathrm{hAPP}_{\text {FAD }}$ mice was ascribed specifically to amyloid deposition (Dickey et al., 2004). However, early plaque formation in our $\mathrm{hAPP}_{\mathrm{FAD}}$ mice did not correlate with Arc expression in granule cells or CA1 pyramidal cells, either at baseline or after environmental exploration (Fig. 6A,B).

To further investigate whether Arc deficits in hAPP mice depend on plaque deposition, we compared TG mice expressing

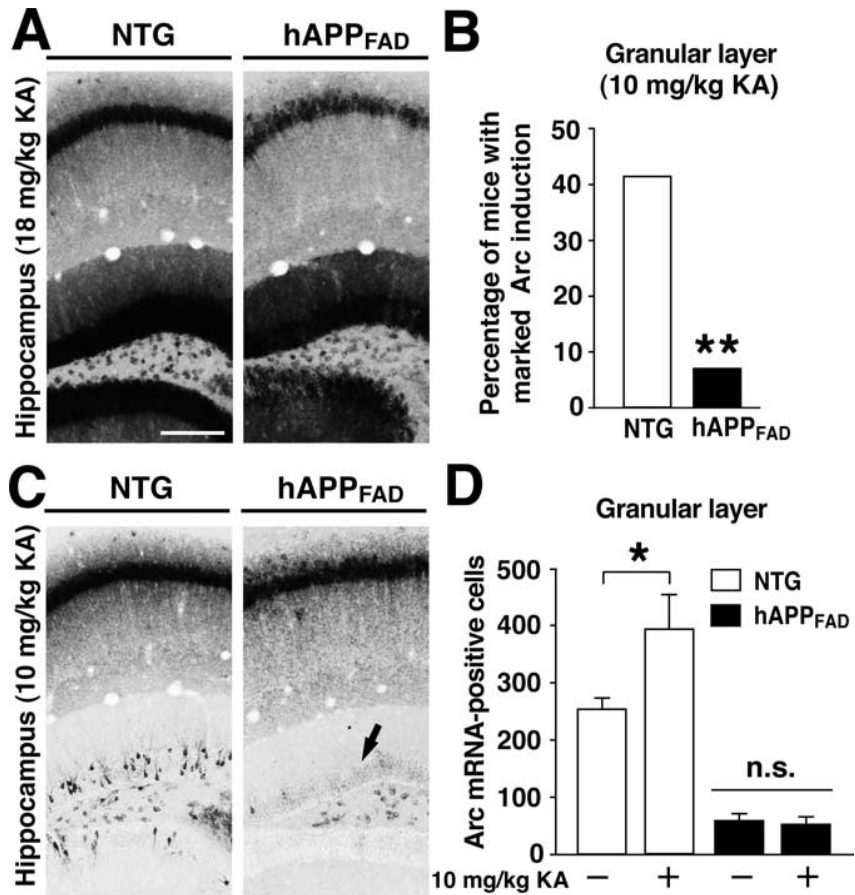

Figure 5. Induction of Arc mRNA expression by kainate. $\boldsymbol{A}$, Very high levels of Arc mRNA in granule cells and CA1 pyramidal cells in NTG and hAPP ${ }_{\text {FAD }}$ mice $2 \mathrm{~h}$ after injection of $18 \mathrm{mg} / \mathrm{kg}$ kainate, which elicited seizures in both groups of mice. Scale bar, $250 \mu \mathrm{m}$. B, Proportion of mice in which injection of $10 \mathrm{mg} / \mathrm{kg}$ kainate resulted in similarly high levels of Arc induction in granule cells but without eliciting obvious seizure activity ( $n=12-15$ per genotype). ${ }^{* *} p<$ 0.01 versus NTG ( $\chi^{2}$ test). $\boldsymbol{C}, \boldsymbol{D}$, In the remaining mice, $10 \mathrm{mg} / \mathrm{kg}$ kainate resulted in more moderate or no induction of $\operatorname{Arc}(\boldsymbol{C})$. Compared with saline-injected controls ( - ) of the same genotype, $10 \mathrm{mg} / \mathrm{kg}$ kainate $(+)$ augmented Arc induction only in NTG controls but not in $\mathrm{hAPP}_{\mathrm{FAD}}$ mice $(\boldsymbol{C}$, arrow; $\boldsymbol{D}) . n=4-5$ mice per genotype for saline; $n=7-14$ per genotype for kainate. ${ }^{*} p<0.05$ (Tukey-Kramer test). Error bars indicate SEM. KA, Kainate.

$\mathrm{hAPP}_{\mathrm{FAD}}$ (line J20) or hAPP $\mathrm{WT}_{\mathrm{T}}$ (line I5). These lines have comparable levels of transgene expression in the brain but different levels of $\mathrm{A} \beta$ (Mucke et al., 2000). A $\beta$ levels are significantly lower in line I5 than in line $\mathrm{J} 20$, and $\mathrm{hAPP}_{\mathrm{WT}}$ mice from line I5 never develop amyloid plaques. However, these hAPP ${ }_{\mathrm{WT}}$ mice clearly have higher $A \beta$ levels than NTG controls and do develop subtle age-dependent synaptic deficits (Mucke et al., 2000). hAPP ${ }_{\mathrm{WT}}$ mice had less severe deficits in Arc and Fos expression than $\mathrm{hAPP}_{\mathrm{FAD}}$ mice (Fig. $6 C, D$ ), suggesting an $\mathrm{A} \beta$ dose effect that is likely independent of plaque formation. Calbindin reductions reached significance only in $\mathrm{hAPP} \mathrm{FAD}_{\mathrm{F}}$ mice, but not in $\mathrm{hAPP}_{\mathrm{WT}}$ mice (Fig. 6E), consistent with previous findings (Palop et al., 2003).

Arc expression deficits in $\mathrm{hAPP} \mathrm{FAD}_{\mathrm{F}}$ mice correlate with depletions of $\alpha$-actinin-2 in the molecular layer Arc induction critically depends on signal transduction cascades triggered by NMDA receptor activation (Lyford et al., 1995; Steward and Worley, 2001). Because the actin-binding protein $\alpha$-actinin-2 plays a key role in the assembly of NMDA receptors in dendritic spines as well as in the modulation of these receptors by $\mathrm{Ca}^{2+}$ (Wyszynski et al., 1997; Krupp et al., 1999), we examined the expression of $\alpha$-actinin- 2 in the molecular layer of the dentate gyrus, where granule cell dendrites receive afferent input.

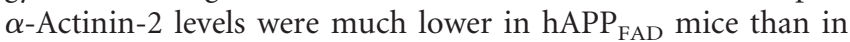
NTG controls and less severely affected in hAPP ${ }_{\mathrm{WT}}$ mice (Figs. $6 \mathrm{~F}$ and $7 A$ ). The reductions in $\alpha$-actinin- 2 correlated tightly with deficits in Arc expression at baseline and after environmental exploration (Fig. 7B), suggesting that deficits in Arc expression 

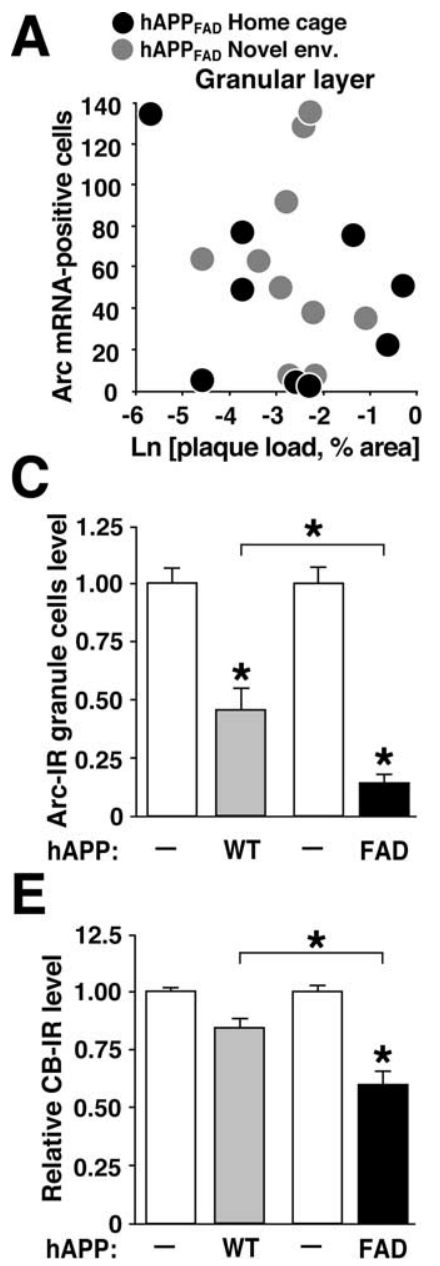

B
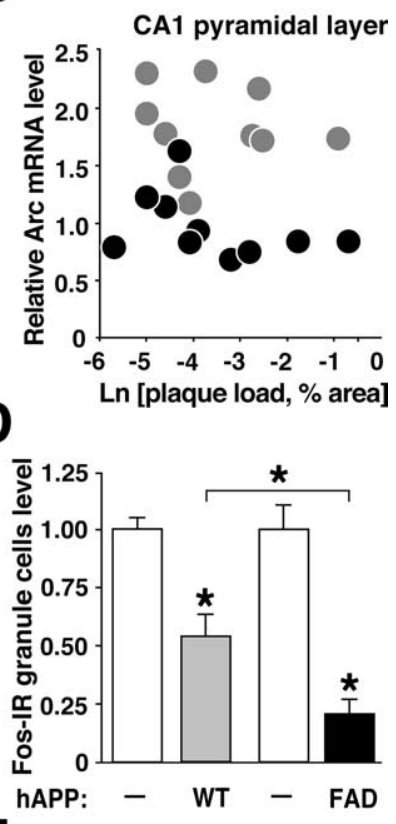

$\mathbf{F}$

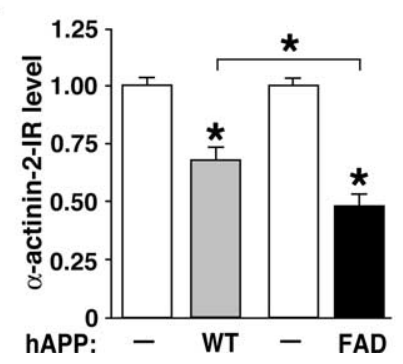

Figure 6. Arc expression in hAPP mice is independent of early plaque formation but influenced by the extent of $A \beta$ production. $A, B$, Arc expression in hAPP ${ }_{F A D}$ mice does not correlate with early plaque formation. Coronal brain sections of $\mathrm{APP}_{\mathrm{FAD}}$ mice that had (gray dots) or had not (black dots) explored a novel environment were immunostained for $A \beta$ deposits or analyzed by in situ hybridization to determine the number of Arc-positive granule cells in the dentate gyrus $(\boldsymbol{A})$ and relative $\operatorname{Arc~mRNA}$ levels in the pyramidal cell layer of the CA1 region (B). At baseline and after exploration, neuronal Arc expression in the granular layer and in CA1 did not correlate with the extent of amyloid deposition in these regions. $C-F$, Molecular profile of granule cells in two hAPP lines with similar levels of hAPP expression but different levels of A $\beta$ (Mucke et al., 2000). Brain sections from TG mice of hAPP WT $_{\text {Ine }} 15$ (畻) and hAPP FAD line J20 $(\square)$ and from NTG littermates of each line $(\square)$ were immunostained for $\operatorname{Arc}(\boldsymbol{C})$, Fos $(\boldsymbol{D})$, calbindin $(\boldsymbol{E})$, or $\alpha$-actinin-2 $(\boldsymbol{F}) . n=9-12$ mice per group; ${ }^{*} p<0.01$ (Tukey-Kramer test). Error bars indicate SEM. Ln, Natural log.

may be related to alterations in excitatory dendritic spines. Reductions in $\operatorname{Arc}$ (Fig. 7C) and $\alpha$-actinin-2 (data not shown) both correlated with calbindin reductions, which have been shown previously to reflect learning and memory deficits in $\mathrm{hAPP} \mathrm{FAD}_{\mathrm{F}}$ mice (Palop et al., 2003), underscoring the potential functional relevance of these molecular alterations.

Decreased activity of the NMDA receptor-dependent signaling pathway in the dentate gyrus of $h A P P_{\mathrm{FAD}}$ mice To assess more directly whether alterations in NMDA receptordependent signaling might be responsible for Arc expression deficits in hAPP $\mathrm{FAD}$ mice, we examined phosphorylation of tyrosine 1472 of the NR2B subunit, which increases the activity of NMDA receptors (Moon et al., 1994; Wang and Salter, 1994) and is associated with LTP induction (Rosenblum et al., 1996; Rostas et al., 1996). Western blot analysis of the dentate gyrus revealed marked
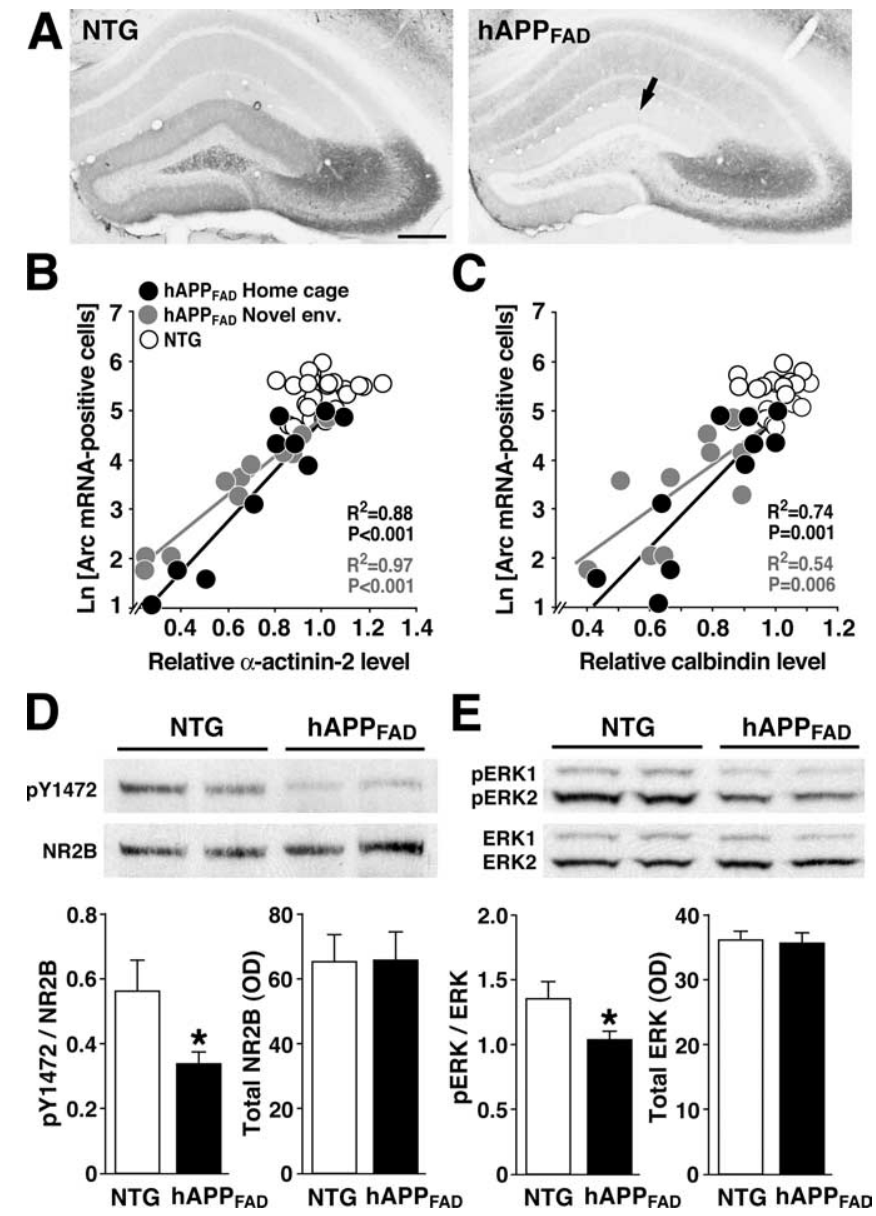

Figure 7. Deficits in Arc expression are associated with reductions in key components of the NMDA receptor-dependent signaling pathway. $A-C$, Arc expression deficits in granule cells of $\mathrm{hAPP}_{\mathrm{FAD}}$ mice are tightly linked to the depletion of $\alpha$-actinin- 2 in the molecular layer of the

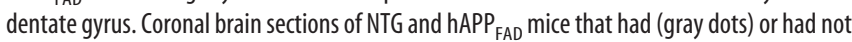
(black dots) explored a novel environment were analyzed by in situ hybridization for Arc or immunostained for $\alpha$-actinin-2 or calbindin. Representative sections in $A$ illustrate robust expression of $\alpha$-actinin- 2 in the molecular layer of an NTG control (left) and depletion of $\alpha$-actinin-2 in the molecular layer of an hAPP FAD mouse (right, arrow). Scale bar, $250 \mu \mathrm{m}$. At baseline and after environmental exploration, granule cell expression of Arc correlated strongly with levels of $\alpha$-actinin-2 (B), calbindin ( $\boldsymbol{C}$, and Fos (data not shown) in hAPP FAD mice but not in NTG controls. $R^{2}$ and $p$ values in $\boldsymbol{B}$ and $\boldsymbol{C}$ refer to hAPP FAD mice only. Novel env., Novel environment; $L n$, natural $\log$. $\boldsymbol{D}, \boldsymbol{E}$, Levels of phosphorylated (activated) NR2B and ERK1/2 are reduced in the dentate gyrus of $\mathrm{hAPP}_{\mathrm{FAD}}$ mice. Western blot analysis of phosphorylated tyrosine residue 1472 of NR2B ( $p$ Y1472) and total NR2B (D) levels and of dually phosphorylated ERK1/2 (pERK1/2) and total ERK1/2 (E) levels illustrates reduced levels of putatively activated NR2B and ERK1/2 in the dentate gyrus of hAPP FAD mice compared with NTG controls. Quantitation of bands on comparable blots (bottom) revealed significant reductions in the ratios of phospho/ total NR2B $(\boldsymbol{D})$ and in phospho/total ERK1/2 $(\boldsymbol{E})$ in hAPP $_{\mathrm{FAD}}$ mice compared with NTG controls and no change in the levels of total NR2B and total ERK1/2.n $=9-10$ mice per genotype. ${ }^{*} p<$ 0.05 (Student's $t$ test). Error bars indicate SEM.

reductions in phosphorylated NR2B in $\mathrm{hAPP}_{\mathrm{FAD}}$ mice compared with NTG controls and no change in total NR2B levels (Fig. 7D).

Calcium influx through NMDA receptors leads to downstream phosphorylation and activation of ERK1/2, MAPK (mitogen-activated protein kinase) family members with activities that are critical for LTP (Thomas and Huganir, 2004). hAPP $\mathrm{FAD}_{\mathrm{F}}$ mice had reduced levels of phosphorylated ERK1/2 in the dentate gyrus, without changes in total ERK1/2 levels (Fig. $7 E$ ). Because phosphorylation of ERK1/2 is an early event in NMDA receptor-mediated signaling, which is necessary for Arc induction (Steward and Worley, 2001), this result further sup- 
ports the notion that Arc deficits in $\mathrm{hAPP}_{\mathrm{FAD}}$ mice may result from impairments in NMDA receptor-mediated signaling.

\section{Discussion}

We used immediate-early gene expression imaging to assess the effects of hAPP/A $\beta$ on activity patterns of neuronal ensembles in the brain. Widespread neuronal expression of hAPP/A $\beta$ impaired both basal and induced expression of Arc predominantly in granule cells of the dentate gyrus. Thus, although granule cells are relatively resistant to degeneration in AD and hAPP mice (West et al., 1994; Palop et al., 2003), they are exquisitely vulnerable to hAPP/A $\beta$-induced dysfunction. The reduced phosphorylation of NR2B and ERK1/2 in the dentate gyrus suggests that this impairment may be attributable, at least in part, to an attenuation of NMDA receptor-dependent signaling. In light of the physiological functions of Arc and the dentate gyrus (Guzowski et al., 2000; Gilbert et al., 2001), disruption of Arc expression in granule cells may contribute critically to deficits in learning and memory in hAPP mice and possibly in AD.

When entire hippocampi of hAPP/presenilin 1 doubly TG mice were analyzed by RT-PCR, basal Arc expression was found to be normal, whereas induced expression was attenuated (Dickey et al., 2004). Our results show that deficits in basal Arc levels in granule cells could easily be obscured by normal basal Arc levels in cells of other hippocampal subfields. Attenuated Arc induction in hAPP/presenilin 1 mice was ascribed specifically to amyloid deposition (Dickey et al., 2004). However, in our $\mathrm{hAPP}_{\mathrm{FAD}}$ mice, Arc expression in granule cells and CA1 pyramidal cells did not correlate with early amyloid deposition, at baseline or after stimulation. Moreover, we found qualitatively similar, albeit smaller, deficits in Arc expression in $\mathrm{hAPP}_{\mathrm{WT}}$ mice from line I5, which never develop plaques (Mucke et al., 2000). Although $\mathrm{A} \beta$ levels are typically lower in $\mathrm{hAPP}_{\mathrm{WT}}$ mice than in

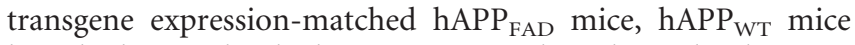
have higher $\mathrm{A} \beta$ levels than NTG controls and can develop agedependent synaptic and behavioral deficits (Moechars et al., 1999; Mucke et al., 2000; Koistinaho et al., 2001). Granule cell expression of Arc and Fos in hAPP ${ }_{\mathrm{WT}}$ mice was indeed lower than in NTG mice and higher than in $\mathrm{hAPP}_{\mathrm{FAD}}$ mice, suggesting an $\mathrm{A} \beta$ dose effect. Our findings support the notion that functional deficits in hAPP mice are more likely caused by small nonfibrillar $\mathrm{A} \beta$ assemblies than by fibrillar $\mathrm{A} \beta$ deposited in amyloid plaques (Hsia et al., 1999; Klein et al., 2001; Walsh and Selkoe, 2004; Cleary et al., 2005).

Independent of which particular $A \beta$ assemblies or hAPP metabolites are responsible for the molecular alterations we identified in hAPP mice, they might act both within the dentate gyrus and in regions projecting to this structure. Indeed, because Arc expression depends on excitatory synaptic activity (Lyford et al., 1995), the special vulnerability of granule cells to $A \beta$-induced disruptions of Arc expression could be attributable to cellautonomous effects and to alterations in network properties. Consistent with the latter possibility, the lines of hAPP mice analyzed in the current study have depletions of synaptophysinimmunoreactive presynaptic terminals in the molecular layer of the dentate gyrus (Mucke et al., 2000), where granule cells receive most of their input. It is also interesting in this regard that the Arc expression deficits in our hAPP mice resembled those in NTG rats after lesioning of the entorhinal cortex (Temple et al., 2003). The entorhinal cortex is affected early in AD (Hyman et al., 1988) and is important in computations that take place before and after cortical information enters the hippocampus (Steffenach et al., 2005). Thus, molecular alterations and synaptic impairments in the molecular layer of the dentate gyrus in hAPP mice may reflect, at least partially, neuronal alterations in laminas II and III of the entorhinal cortex, from which granule cells receive important input.

The results of the current study suggest that $\mathrm{A} \beta$-induced alterations in granule cell input might trigger a vicious cycle that could progressively disable critical hippocampal functions. A decrease in NMDA receptor-dependent signaling, which is critical for the expression of Arc (Steward and Worley, 2001), may be a crucial element of this cycle. In the dentate gyrus of hAPP $\mathrm{FAD}_{\mathrm{F}}$ mice, we found reductions in the phosphorylation states of the NR2B subunit, which regulates the activity of NMDA receptors (Salter and Kalia, 2004), and reductions in the MAPKs ERK1/2, the activities of which are regulated by NMDA receptors (Thomas and Huganir, 2004). In agreement with our in vivo results, it has been demonstrated recently in primary neuronal cultures that $\mathrm{A} \beta$ promotes dephosphorylation of the NR2B subunit and endocytosis of NMDA receptors, attenuating NMDAevoked currents and NMDA-dependent signaling pathways (Snyder et al., 2005).

Notably, an experimental reduction in Arc expression in the rat hippocampus impaired maintenance of LTP and consolidation of long-term memory (Guzowski et al., 2000). hAPP $\mathrm{FAD}$ mice from line $\mathrm{J} 20$ also show deficits in learning and memory that correlate tightly with depletions of calbindin and Fos in granule cells of the dentate gyrus (Palop et al., 2003), which in turn correlated with Arc deficits in the current study. Because Arc appears to participate in the modification of activated synapses as an anchoring or targeting protein (Lyford et al., 1995; Guzowski et al., 2000), its reduction could destabilize dendritic spines and contribute to reductions in other synaptic activity-dependent proteins, including Fos, calbindin, and $\alpha$-actinin-2, further impairing learning and memory (Molinari et al., 1996; Guzowski, 2002). Alterations in $\alpha$-actinin- 2 and calbindin could in turn impair NMDA receptor signaling (Wyszynski et al., 1997; Krupp et al., 1999; Nägerl et al., 2000), on which Arc expression depends (Lyford et al., 1995; Steward and Worley, 2001).

Because Arc and related factors seem to be intimately involved in the encoding of specific environmental contexts (Guzowski et al., 1999; Vazdarjanova and Guzowski, 2004), the vicious cycle described above would be expected to disrupt the recruitment of granule cell ensembles during acquisition of contextual information. It is tempting to speculate that this process contributes critically to the visuospatial disabilities of hAPP mice and of patients with AD. The obliteration of encoding activity in specific neuronal populations involved in learning and memory may also contribute more generally to the impairments of declarative memory in early $\mathrm{AD}$ and to the inexorable loss of memory and other cognitive functions later on. The vicious cycle triggered by impairments in molecular pathways that both depend on and regulate synaptic activity might be broken not only by decreasing $\mathrm{A} \beta$ levels in the brain but also by normalizing synaptic plasticity. These approaches are not mutually exclusive and, in combination, might provide additive or synergistic therapeutic benefits.

\section{References}

Braak H, Braak E (1991) Neuropathological stageing of Alzheimer-related changes. Acta Neuropathol 82:239-259.

Burke SN, Chawla MK, Penner MR, Crowell BE, Worley PF, Barnes CA, McNaughton BL (2005) Differential encoding of behavior and spatial context in deep and superficial layers of the neocortex. Neuron 45:667-674.

Cleary JP, Walsh DM, Hofmeister JJ, Shankar GM, Kuskowski MA, Selkoe DJ, Ashe KH (2005) Natural oligomers of the amyloid- $\beta$ protein specifically disrupt cognitive function. Nat Neurosci 8:79-84. 
Corder EH, Woodbury MA, Volkmann I, Madsen DK, Bogdanovic N, Winblad B (2000) Density profiles of Alzheimer disease regional brain pathology for the huddinge brain bank: pattern recognition emulates and expands upon Braak staging. Exp Gerontol 35:851-864.

Dickey CA, Loring JF, Montgomery J, Gordon MN, Eastman PS, Morgan D (2003) Selectively reduced expression of synaptic plasticity-related genes in amyloid precursor protein + presenilin-1 transgenic mice. J Neurosci 23:5219-5226.

Dickey CA, Gordon MN, Mason JE, Wilson NJ, Diamond DM, Guzowski JF, Morgan D (2004) Amyloid suppresses induction of genes critical for memory consolidation in APP + PS1 transgenic mice. J Neurochem 88:434-442.

Eustache F, Piolino P, Giffard B, Viader F, De La Sayette V, Baron JC, Desgranges B (2004) "In the course of time": a PET study of the cerebral substrates of autobiographical amnesia in Alzheimer's disease. Brain 127:1549-1560.

Games D, Adams D, Alessandrini R, Barbour R, Berthelette P, Blackwell C, Carr T, Clemens J, Donaldson T, Gillespie F, Guido T, Hagopian S, Johnson-Wood K, Khan K, Lee M, Leibowitz P, Lieberburg I, Little S, Masliah E, McConlogue L, et al. (1995) Alzheimer-type neuropathology in transgenic mice overexpressing V717F $\beta$-amyloid precursor protein. Nature 373:523-527.

Gilbert PE, Kesner RP, Lee I (2001) Dissociating hippocampal subregions: A double dissociation between dentate gyrus and CA1. Hippocampus 11:626-636.

Guzowski JF (2002) Insights into immediate-early gene function in hippocampal memory consolidation using antisense oligonucleotide and fluorescent imaging approaches. Hippocampus 12:86-104.

Guzowski JF, McNaughton BL, Barnes CA, Worley PF (1999) Environment-specific expression of the immediate-early gene Arc in hippocampal neuronal ensembles. Nat Neurosci 2:1120-1124.

Guzowski JF, Lyford GL, Stevenson GD, Houston FP, McGaugh JL, Worley PF, Barnes CA (2000) Inhibition of activity-dependent arc protein expression in the rat hippocampus impairs the maintenance of long-term potentiation and the consolidation of long-term memory. J Neurosci 20:3993-4001.

Higgins GA, Jacobsen H (2003) Transgenic mouse models of Alzheimer's disease: phenotype and application. Behav Pharmacol 14:419-438.

Hsia A, Masliah E, McConlogue L, Yu G, Tatsuno G, Hu K, Kholodenko D, Malenka RC, Nicoll RA, Mucke L (1999) Plaque-independent disruption of neural circuits in Alzheimer's disease mouse models. Proc Natl Acad Sci USA 96:3228-3233.

Hyman BT, Kromer LJ, Van Hoesen GW (1988) A direct demonstration of the perforant pathway terminal zone in Alzheimer's disease using the monoclonal antibody Alz-50. Brain Res 450:392-397.

Klein WL, Krafft GA, Finch CE (2001) Targeting small A $\beta$ oligomers: the solution to an Alzheimer's disease conundrum. Trends Neurosci 24:219-224.

Kobayashi DT, Chen KS (2005) Behavioral phenotypes of amyloid-based genetically modified mouse models of Alzheimer's disease. Genes Brain Behav 4:173-196.

Koistinaho M, Ort M, Cimadevilla JM, Vondrous R, Cordell B, Koistinaho J, Bures J, Higgins LS (2001) Specific spatial learning deficits become severe with age in $\beta$-amyloid precursor protein transgenic mice that harbor diffuse $\beta$-amyloid deposits but do not form plaques. Proc Natl Acad Sci USA 98:14675-14680.

Krupp JJ, Vissel B, Thomas CG, Heinemann SF, Westbrook GL (1999) Interactions of calmodulin and $\alpha$-actinin with the NR1 subunit modulate $\mathrm{Ca}^{2+}$-dependent inactivation of NMDA receptors. J Neurosci 19:1165-1178.

Lyford GL, Yamagata K, Kaufmann WE, Barnes CA, Sanders LK, Copeland NG, Gilbert DJ, Jenkins NA, Lanahan AA, Worley PF (1995) Arc, a growth factor and activity-regulated gene, encodes a novel cytoskeletonassociated protein that is enriched in neuronal dendrites. Neuron 14:433-445.

Moechars D, Dewachter I, Lorent K, Reverse D, Baekelandt V, Naidu A, Tesseur I, Spittaels K, Van Den Haute C, Checler F, Godaux E, Cordell B, Van Leuven F (1999) Early phenotypic changes in transgenic mice that overexpress different mutants of amyloid precursor protein in brain. J Biol Chem 274:6483-6492.

Molinari S, Battini R, Ferrari S, Pozzi L, Killcross AS, Robbins TW, Jouvenceau A, Billard J-M, Dutar P, Lamour Y, Baker WA, Cox H, Emson PC
(1996) Deficits in memory and hippocampal long-term potentiation in mice with reduced calbindin $\mathrm{D}_{28 \mathrm{~K}}$ expression. Proc Natl Acad Sci USA 93:8028-8033.

Moon IS, Apperson ML, Kennedy MB (1994) The major tyrosinephosphorylated protein in the postsynaptic density fraction is $N$-methylD-aspartate receptor subunit 2B. Proc Natl Acad Sci USA 91:3954-3958.

Mucke L, Masliah E, Yu G-Q, Mallory M, Rockenstein EM, Tatsuno G, Hu K, Kholodenko D, Johnson-Wood K, McConlogue L (2000) High-level neuronal expression of $\mathrm{A} \beta_{1-42}$ in wild-type human amyloid protein precursor transgenic mice: synaptotoxicity without plaque formation. J Neurosci 20:4050-4058.

Nägerl UV, Mody I, Jeub M, Lie AA, Elger CE, Beck H (2000) Surviving granule cells of the sclerotic human hippocampus have reduced $\mathrm{Ca}^{2+}$ influx because of a loss of calbindin- $\mathrm{D}_{28 \mathrm{~K}}$ in temporal lobe epilepsy. J Neurosci 20:1831-1836.

Palop JJ, Jones B, Kekonius L, Chin J, Yu G-Q, Raber J, Masliah E, Mucke L (2003) Neuronal depletion of calcium-dependent proteins in the dentate gyrus is tightly linked to Alzheimer's disease-related cognitive deficits. Proc Natl Acad Sci USA 100:9572-9577.

Rockenstein EM, McConlogue L, Tan H, Gordon M, Power M, Masliah E, Mucke L (1995) Levels and alternative splicing of amyloid $\beta$ protein precursor (APP) transcripts in brains of transgenic mice and humans with Alzheimer's disease. J Biol Chem 270:28257-28267.

Rosenblum K, Dudai Y, Richter-Levin G (1996) Long-term potentiation increases tyrosine phosphorylation of the $N$-methyl-D-aspartate receptor subunit $2 \mathrm{~B}$ in rat dentate gyrus in vivo. Proc Natl Acad Sci USA 93:10457-10460.

Rostas JA, Brent VA, Voss K, Errington ML, Bliss TV, Gurd JW (1996) Enhanced tyrosine phosphorylation of the $2 \mathrm{~B}$ subunit of the $N$-methyl-Daspartate receptor in long-term potentiation. Proc Natl Acad Sci USA 93:10452-10456.

Sadek JR, Johnson SA, White DA, Salmon DP, Taylor KI, Delapena JH, Paulsen JS, Heaton RK, Grant I (2004) Retrograde amnesia in dementia: comparison of HIV-associated dementia, Alzheimer's disease, and Huntington's disease. Neuropsychology 18:692-699.

Salter MW, Kalia LV (2004) Src kinases: a hub for NMDA receptor regulation. Nat Rev Neurosci 5:317-328.

Snyder EM, Nong Y, Almeida CG, Paul S, Moran T, Choi EY, Nairn AC, Salter MW, Lombroso PJ, Gouras GK, Greengard P (2005) Regulation of NMDA receptor trafficking by amyloid- $\beta$. Nat Neurosci 8:1051-1058.

Steffenach HA, Witter M, Moser MB, Moser EI (2005) Spatial memory in the rat requires the dorsolateral band of the entorhinal cortex. Neuron 45:301-313.

Steward O, Worley PF (2001) Selective targeting of newly synthesized Arc mRNA to active synapses requires NMDA receptor activation. Neuron 30:227-240.

Temple MD, Worley PF, Steward O (2003) Visualizing changes in circuit activity resulting from denervation and reinnervation using immediate early gene expression. J Neurosci 23:2779-2788.

Thomas GM, Huganir RL (2004) MAPK cascade signalling and synaptic plasticity. Nat Rev Neurosci 5:173-183.

Vazdarjanova A, Guzowski JF (2004) Differences in hippocampal neuronal population responses to modifications of an environmental context: evidence for distinct, yet complementary, functions of CA3 and CA1 ensembles. J Neurosci 24:6489-6496.

Walsh DM, Selkoe DJ (2004) Deciphering the molecular basis of memory failure in Alzheimer's disease. Neuron 44:181-193.

Wang YT, Salter MW (1994) Regulation of NMDA receptors by tyrosine kinases and phosphatases. Nature 369:233-235.

West MJ, Slomianka L, Gundersen HJG (1991) Unbiased stereological estimation of the total number of neurons in the subdivisions of the rat hippocampus using the optical fractionator. Anat Rec 231:482-497.

West MJ, Coleman PD, Flood DG, Troncoso JC (1994) Differences in the pattern of hippocampal neuronal loss in normal ageing and Alzheimer's disease. Lancet 344:769-772.

Wiltgen BJ, Brown RA, Talton LE, Silva AJ (2004) New circuits for old memories: the role of the neocortex in consolidation. Neuron 44:101-108.

Wyszynski M, Lin J, Rao A, Nigh E, Beggs AH, Craig AM, Sheng M (1997) Competitive binding of $\alpha$-actinin and calmodulin to the NMDA receptor. Nature 385:439-442. 